\title{
Evaluation of phenyl pyrazole for the managaement of yellow stem borer Scirpophaga incertulas Walker in rice
}

\author{
PAIDI SATYANARAYANA, M. RAGHURAMAN* AND SANTESHWARI
}

Department of Entomology and Agricultural Zoology, Institute of Agricultural Sciences, Banaras Hindu University, VARANASI (U.P.) INDIA

\section{ARITCLE INFO}

Received : 22.05 .2014

Revised : 03.08 .2014

Accepted : 18.08 .2014

KEY WORDS :

Fipronil, Phenyl pyrazole, Yellow stem borer, Scirpophaga incertulas

*Corresponding author:

Email:raghu_iari@yahoo.com

\begin{abstract}
Field experiment was conducted at Banaras Hindu University research farm, Varanasi, on hybrid rice variety PHB 71 during Kharif season of 2012 to study impact of granular formulation of phenyl pyrazole on rice yellow stem borer, Scirpophaga incertulas (Walker). Results revealed that in terms of efficacy against stem borer, overall performance of various spraying insecticidal treatments based on the mean indicated that treatment with Fipronil 0.6 per cent GR @ 60g a.i./ha was the most effective and significantly superior over all other treatments in reducing the dead hearts to minimum level of 3.40 per cent. Fipronil 0.6 per cent GR @ 50g a.i./ha stood second in order of effectiveness which recorded 4.45 per cent dead hearts. The Carbofuran 3 GR @ 750g a.i./ha. proved least effective in which higher per cent of dead hearts of 5.08 were observed. The untreated control recorded 6.88 per cent dead hearts.
\end{abstract}

How to view point the article : Satyanarayana, Paidi, Raghuraman, M. and Santeshwari (2014). Evaluation of phenyl pyrazole for the managaement of yellow stem borer Scirpophaga incertulas Walker, in rice. Internat. J. Plant Protec., 7(2) : 360-363. 